\title{
CHALLENGES AND STRATEGIES ON IMPLEMENTING AN ECOLOGICAL CORRIDOR BETWEEN PROTECTED AREAS IN CERRADO BIOME ${ }^{1}$
}

\author{
Samuel Fernando Schwaida ${ }^{2 *}$, Rejane Ennes Cicerelli², Tati de Almeida² and Henrique Llacer Roig ${ }^{2}$
}

\footnotetext{
${ }^{1}$ Received on 24.04.2017 accepted for publication on 27.11.2017.

${ }^{2}$ Universidade de Brasília, Instituto de Geociências , Brasília, DF - Brasil. E-mail: <samuelschwaida@gmail.com>, <rejaneig@unb.br>, <tati_almeida@unb.br>and<roi@unb.br>.

*Corresponding author.
}

\begin{abstract}
Landscape management aiming to reconnect isolated vegetation patches through corridors is important to mitigate impacts on fauna and flora species due to habitat degradation and fragmentation. This work presents a methodology based on geoprocessing tools to define ecological corridors. This case study was conducted on Distrito Federal, central Brazil, aiming to propose a corridor for large and mediumsized mammals reconnecting Águas Emendadas Ecological Station and Formosa Military Training Area. Cost analysis using geoprocessing tools and available official database generated three paths (A, B, C) Extension varied from 28.88 (A) to $47.34 \mathrm{~km}$ (C) and paths intersection with natural vegetation patches varied from 74.43 (A) to $90.35 \%$ (B). Intersection with potential Permanent Preservation Areas (APPs) varied from 66.32 (A) to $86.26 \%$ (C). Overlap with private properties registered on Rural Environmental Registry (CAR) was verified for best paths A and B and revealed $51.60 \%$ and $50.97 \%$ of overlap. Cost analysis tools and AHP were considered efficient for generating ecological corridors.
\end{abstract}

Keywords: Landscape ecology; Multicriteria analysis; Geo-technologies

\section{DESAFIOS E ESTRATÉGIAS NA IMPLEMENTAÇÃO DE CORREDORES ECOLÓGICOS ENTRE ÁREAS PROTEGIDAS NO BIOMA CERRADO}

\begin{abstract}
RESUMO - Medidas que visem a reconectar a paisagem, como corredores ecológicos, são de suma importância para reverter os impactos da degradação e fragmentação de habitats sobre a biodiversidade. Este trabalho propõe uma metodologia que utiliza ferramentas de geoprocessamento para definição de corredores ecológicos. O estudo de caso foi realizado no limite estadual do Distrito Federal e Goiás com intuito de propor um corredor ecológico para mamíferos de médio e grande entre a Estação Ecológica de Águas Emendadas e o Campo de Instrução de Formosa. As análises de custo realizadas utilizando dados oficiais gratuitos resultaram em três trajetos ( $A, B, C$ ), com extensões variando de 28,88 (A) a 47,34 km (C). A sobreposição dos trajetos com remanescentes de vegetação natural variou de 74,43\% (A) a 90,35\% (B) e a intersecção com APP potenciais de 66,32\% (A) a 86,26\% (C). A sobreposição com propriedades rurais cadastradas no CAR (Cadastro Ambiental Rural) foi analisada para os melhores caminhos A e B, revelando 51,60\% e 50,97\% de sobreposição, respectivamente, indicando áreas predispostas para o processo de regularização ambiental. O uso das ferramentas de análise de custo aliado ao método AHP mostrou-se eficiente para delimitação de corredores ecológicos.
\end{abstract}

Palavras-Chave: Ecologia da paisagem; Análise multicritério; Geotecnologias

Revista Árvore. 2017;41(6):e410611

http://dx.doi.org/10.1590/1806-90882017000600011 


\section{INTRODUCTION}

Habitat loss, and fragmentation are major threats to biodiversity. Division of continuous areas of original vegetation into isolated fragments results in the separation of populations, reduces the quality of habitats, and can also threaten the long-term viability of some populations of species (Vitousek et al., 1997; Lang and Blaschke, 2009). These effects are felt especially by those species with high energy requirements such as medium to large sized mammals and top predators in the food chain (Fahrig, 2003; Tabarelli and Gascon, 2005; Forero-Medina and Vieira, 2009).

Faced with the implications of fragmentation on biodiversity, the concept of "defragmentation" was introduced, and defined as the reduction or elimination of fragmentation to landscapes, making them more permeable to wildlife (Lang and Blaschke, 2009; Seoane et al., 2010). Defragmentation can be achieved, for example, through the placement of habitats in a network using Ecological Corridors (EC), a term that generally refers to a narrow element of linear connectivity between two separate habitats that meets the ecological requirements of certain species (Chetkiewicz et al., 2006; Lang and Blaschke, 2009; Seoane et al., 2010).

In Brazil, the EC are part of public policies since the 1990s, following the example of CONAMA Resolution 9/1996 (Brasil, 1996), a Pilot Program for the Protection of the Tropical Forests in Brazil (PPG-7) and the National System of Conservation Units (SNUC) (Mittermeir et al., 2005; Akashi and Castro, 2010). Despite this legal framework, implementation is still incipient largely because the creation of ECs is complex and involves the integration of several biotic and abiotic factors to guarantee structural and functional connectivity aimed at the maintenance of living areas, resources and reproductive processes (Lang and Blaschke, 2009; Seoane et al., 2010).

In Brazil, some studies have made use of geoprocessing tools in Geographic Information Systems (GIS) in order to identify the best routes or best areas for implementation of Ecological Corridors, with distinct methods focused on the Atlantic Forest biome (Muchailh et al., 2010; Louzada et al., 2013; Ferrari et al., 2012; Oliveira et al., 2015; Saito et al., 2016). For the Cerrado (Savanna) biome, little related to these ideas has been explored, despite being one of the richest savannas in the world, and almost half of its original area being rapidly and systematically converted to production activities over the last 45 years (Klink and Machado, 2005; Brasil, 2015). Moreover, the Cerrado has the lowest percentage of area under full federal protection - just 8.6\% -, consisting mostly of, isolated patches of difficult connectivity (Brasil, 2015).

Thus, this work aims to propose a methodology for defining the routes of Ecological Corridors for medium and large sized mammals in specific areas of the Cerrado Biome located in central Brazil. The idea is to connect two fragmented areas of high importance for the conservation of biodiversity in the Federal District and following surrounding areas: the Águas Emendadas Ecological Station, a District Conservation Unit, and Formosa Military Training Area. Rural properties registered in the Rural Environmental Registry (Cadastro Ambiental Rural - CAR) were analyzed, observing the feasibility of the installation of Ecological Corridors based on the legal forecast for maintenance of APP and Legal Reserve.

\section{MATERIALS AND METHODS}

The study area covers $4,468 \mathrm{~km}^{2}$ and is located in the eastern portion of the Federal District of Brazil, and also the southern portion of the municipality of Formosa, Goiás State. It encompasses Águas Emendadas Ecological Station (Estação Ecológica de Águas Emendadas - ESECAE), the Formosa Military Training Area (Campo de Instrução de Formosa - CIF) and a small strip of nearby municipalities (Figure 1). There is a high number of roads and highways and, based on calculations done using "Project TerraClass 2013" data (Brasil, 2015), 47.52\% of the area is devoted to the remaining vegetation, $28.25 \%$ to agriculture and $20.59 \%$ to pasture. Although part of the area is protected by the Environmental Protection Areas (APA) of the São Bartolomeu River Basin and the Central Plateau, both federal Conservation Units (CU), as well as part of the Cerrado Biosphere Reserve, legal protection is not enough to avoid conversion of the landscape. Much of this is due to a lack of planning, area's proximity to urban centers and favorable conditions for agricultural production (Secretaria de Desenvolvimento Urbano e Meio Ambiente, 2008).

ESECAE is a District Conservation Unit geared to full protection and managed by the Institute of Environment and Water Resources for the Federal District Brasilia Ambiental (IBRAM), located in the administrative

Revista Árvore. 2017;41(6):e410611 
region of Planaltina, DF. With a total area of 10,547.2 ha, the space is made up of Cerradão ("high Cerrado"), also known as savanna woodland with an almost closed canopy (12-15 m tree height), and is found mainly along the forest-savanna border. Cerrado sensu stricto or wooded savanna (>15\% tree cover, frequently 20-30\%), the most extensive savanna type in Brazil, makes up open Cerrado with a relatively open cover and dense Cerrado with a denser cover. Cerrado grasslands (Formação Campestre) are divided into: Campo limpo or open savanna (2-15\% canopy cover); Campo sujo or scrubland, open savanna with scattered trees $(<2 \mathrm{~m})$ or shrubs with $<5 \%$ canopy cover; and Campo limpo or grassland and forest gallerys along the water paths (Sano et al., 2005; Ribeiro and Walter, 1998; BatlleBayer et al, 2010). ESECAE is based on a main polygon surrounded by four highways (south: BR-030; west: DF-128; north: DF-205; east: BR-010), a situation that hinders the movement of fauna and contributes to cases of trampling around ESECAE, estimated at 2,464 deaths per year, of at least 100 species, including some threatened species (Secretaria de Desenvolvimento Urbano e Meio Ambiente, 2008; Brasil, 2014b). Apart from its importance for water sources protection, ESECAE is home to 67 species of mammals such as the maned wolf (Chrysocyon brachiurus), the puma (Puma concolor), and anteater (Mymercophaga tridactyla), classified as threatened species by the Ministry of the Environment (Secretaria de Desenvolvimento Urbano e Meio Ambiente, 2008; Brasil, 2014b). In 2014, researchers recorded the sighting of an individual jaguar (Panthera onca), a species that had not been observed in the region for a very long time (Instituto Chico Mendes de Conservação da Biodiversidade, 2015).

According to Arimoro (2015), the Training Area of the 6th Group of Multiple Rocket Launchers - Astro II (CIF) is a military zone belonging to the Brazilian Army and used to carry out training exercises. Located in the municipality of Formosa, GO (Figure 1) its approximate area is 117,000 ha with natural vegetation cover formed by wooded cerrado, open savanna, scrubland and forest gallery. A survey of medium and large mammals by Arimoro recorded 26 species, of which eight are classified as threatened, including those at the top predators such as jaguars and pumas.

The method used to generate the Ecological Corridors between the two protected areas above was based on the geoprocessing tool 'Least Cost Path', which allows for the identification of the most efficient pathways between two points on a cost surface. The cost surface image was generated from four input layers, corresponding to variables influencing the movement of medium and large sized mammals and the implementation of EC: (1) Land cover and use, (2) Roads, (3) Permanent Preservation Areas and (4) Slope (Table 1). The default cell size was $30 \mathrm{~m}$, the same spatial resolution as the Land cover and use data and the Digital Elevation Model used. The entire process was performed using ArcGIS 10.3 software (Environmental Systems Research Institute, 2014).

Slope information was generated using images from SRTM (Shuttle Radar Topography Mission), obtained from the U.S. Geological Survey website (spatial resolution of $30 \mathrm{~m}$ ). After generating the image with slope information reclassified in degrees, data was reclassified with three break values: $<20^{\circ}$ (mechanically agricultural), $45^{\circ}$ (restricted use), and $>45^{\circ}$ (Permanent Preservation Area), according to Louzada et al. (2013).

The matrix layer image of the Permanent Preservation Area (Área de Preservação Permanente - APP), corresponding just to the marginal range of water resources, was generated using the vector drainage data provided by IBRAM. We selected features classified as perennial and generated a buffer with a radius of 30m, the minimum width required by law 12.651/2012 (New Forest Code) for rivers less than $10 \mathrm{~m}$ wide, representing potential APP areas.

The matrix image of the road layer was generated from the vector file of DER/DF (year 2012, scale 1:10.000), available in the metadata portal of the State Secretariat for Territorial Management and Housing (SEGETH), of the Federal District of Brazil. The sections of road were extended out to the limits of the study area and information related to paving was updated based on the Orthophoto of 2015 available by the Planning Commission of the Federal District (CODEPLAN). Identification of bridges was made and corresponding segments were removed considering that underpasses facilitate fauna movement and reduce the chances of roadkill (Van Der Grift et al., 2013).

The land use and land cover data were obtained from the project TerraClass Cerrado 2013 (Brasil, 2015), at scale $1: 250,000$. The classes of land use and land cover in the study area are: Annual Crop, Perennial Crop, Pasture, Water Bodies, Forestry, Urban Area,

Revista Árvore. 2017;41(6):e410611 
Mosaic of Uses, Exposed Soil, Natural Vegetation and Non-observed. Urban area and Mosaic of Uses were considered as a single class in the analysis. The "Nonobserved" class $(0.1 \%$ of the total area) was verified using RapidEye images from the year 2013 with 5m resolution. The importance degree for costs and layers - necessary for the EC path generation - were defined through Hierachical Analysis Process (AHP), development by Saaty (2008).

The cost-related assessment between each class in each layer, as well as the importance degree of each layer for the EC path generation was done by using comparison matrices filled in with defined values, which were established based on the information available in the literature and consultation, by means of a survey of specialists in the field of biology and conservation, seeking a Consistency Ratio (CR) of less than 0.10 , as describedby Saaty (2008). Fromthenormalized comparison matrices, we calculated the final weights for the total cost matrix image generated by Weighted Overlay tool, adding the weights of each layer - in percentages with total sum equal to $100 \%$ - as well as the class weights for each layer-at a 1 to 9 scale, according to the values presented in Table 1.

From the total cost matrix image, the Cost Distance and Cost Direction images were generated (Backlink), and formed the basis for constructing the least-cost paths (Each Cell) and the best single path (Best Single). Results were vectorized and each path was analyzed individually as to its length and intersection with the information classes, APP and Bridges. A buffer with a radius of $5 \%$ of the total length of the path was also generated, for each corridor, following Resolution CONAMA n ${ }^{\circ}$ 9, of October 24, 1996, which previously sets the EC width at $10 \%$ of its total length. The total area of each corridor was calculated as well as its overlap with land use classes and rural property boundaries provided by IBRAM - data received by the agency until May 2016, within the framework of the Rural Environmental Registry (CAR). Because this data was not officially validated, for the purposes of this work, verification and correction were made for overlapping of features, and gaps, between property boundaries with the aid of RapidEye images, resolution 5m, year 2013.

Table 1 - Weights for each class (1-9 scale) and for each layer (\%) used for the total cost raster and values for Consistency Index (IC) and Consistency Ratio (RC). * Considering line segments corresponding to bridges were depleted, associated cells received the least cost value considering they represent least cost crossing locations ** Weight for "Nonobserved" refers to the mean of weights of those classes identified in validation process (Exposed soil and Natural Vegetation).

Tabela 1 - Pesos finais de cada classe (escala de 1 a 9) e peso de cada camada (\%) na geração da imagem de custo total e valores dos Índice de Consistência (IC) e Razão de Consistência (RC). * Considerando a retirada dos segmentos correspondentes a pontes, as respectivas células receberam o menor valor de custo por representarem pontos de menor custo para travessia da fauna. ** O valor da classe não observado equivale a média das classes identificadas na validação (Solo exposto e Vegetação Natural).

\begin{tabular}{|c|c|c|c|c|c|}
\hline Layer & Layer weight & Class & Class weight & Justification & $\mathrm{IC} ; \mathrm{RC}$ \\
\hline \multirow[t]{2}{*}{ Slope } & \multirow[t]{2}{*}{$5 \%$} & $>45^{\circ}$ & 1 & Lower slope terrains are suitable for & \multirow[b]{2}{*}{$0.01 ; 0.01$} \\
\hline & & $\begin{array}{l}20^{\circ}-45^{\circ} \\
<20^{\circ}\end{array}$ & $\begin{array}{l}3 \\
9\end{array}$ & $\begin{array}{l}\text { mechanized agriculture, thus implying higher } \\
\text { costs for corridors implementation. }\end{array}$ & \\
\hline Permanent & \multirow[t]{3}{*}{$15 \%$} & No & 9 & APP are appropriate areas for corridors. & \multirow{3}{*}{-0.5 ; null } \\
\hline Preservation & & Yes & 1 & Areas outside of APP increase & \\
\hline Area (APP) & & & & implementation cost & \\
\hline \multirow[t]{3}{*}{ Roads } & \multirow[t]{3}{*}{$25 \%$} & Absent & $1 *$ & Paving favors higher vehicle flow & \multirow{3}{*}{0,$03 ; 0,04$} \\
\hline & & Unpaved & 3 & and increases impacts & \\
\hline & & Paved & 9 & (disturbance, barrier, trampling) & \\
\hline \multirow{9}{*}{$\begin{array}{l}\text { Land use } \\
\text { and cover }\end{array}$} & \multirow[t]{9}{*}{$55 \%$} & Natural Vegetation & 1 & \multirow{9}{*}{$\begin{array}{l}\text { Fauna will preferably move through natural } \\
\text { environments and possibly through less } \\
\text { disturbed areas or with any vegetation cover, } \\
\text { such as reforestation and agriculture. }\end{array}$} & \multirow{9}{*}{$0.13 ; 0.09$} \\
\hline & & Forestry & 2 & & \\
\hline & & Pasture & 3 & & \\
\hline & & Perennial crop & 3 & & \\
\hline & & Non-observed & $3 * *$ & & \\
\hline & & Annual crop & $\begin{array}{l}4 \\
5\end{array}$ & & \\
\hline & & $\begin{array}{l}\text { Exposed soll } \\
\text { Water bodies }\end{array}$ & $\begin{array}{l}5 \\
6\end{array}$ & & \\
\hline & & Urban area/ & 9 & & \\
\hline & & Mosaic of uses & & & \\
\hline
\end{tabular}

Revista Árvore. 2017;41(6):e410611 


\section{RESULTS}

The normalization of the Comparison Matrices indicated the use and coverage of the soil as a major factor (55\%) for generating Ecological Corridors and slope as the least important (5\%). Regarding land use and land cover classes, natural vegetation was considered the one with smaller impedance for fauna movement (1), and urban area was the major impedance. Pasture and agricultural areas received intermediate values $(3,4)$. Areas of perennial crop were considered less of an impedance (3) than areas of annual crop (4). Weights assigned to each layer and each class of land use and cover are shown in Table 1.

The cost analysis generated four routes from the 'Each Cell' option and a single best path from the 'Best Single’ option (Figure 1). Two corridors presented a $89 \%$ and $98 \%$ overlap with the best single path and were disregarded. Subsequent analyzes were limited to three tracings named A, B (best single path) and $C$ The length of these routes ranged from $28.88 \mathrm{~km}$ (A) to $47.34 \mathrm{~km}$ (C), with a stretch of $10 \mathrm{~km}$ common to both corridors $\mathrm{B}$ and $\mathrm{C}$. The routes intersection with natural vegetation areas ranged from $74.43 \%$ (A) to $90.35 \%$ (B). All paths had more than $60 \%$ of the route in potential APPs - 66.32\% (A), 84.13\% (B) and 86.26\% (C) - and in all of them more than $94 \%$ of the potential APP zones corresponded to natural vegetation. All

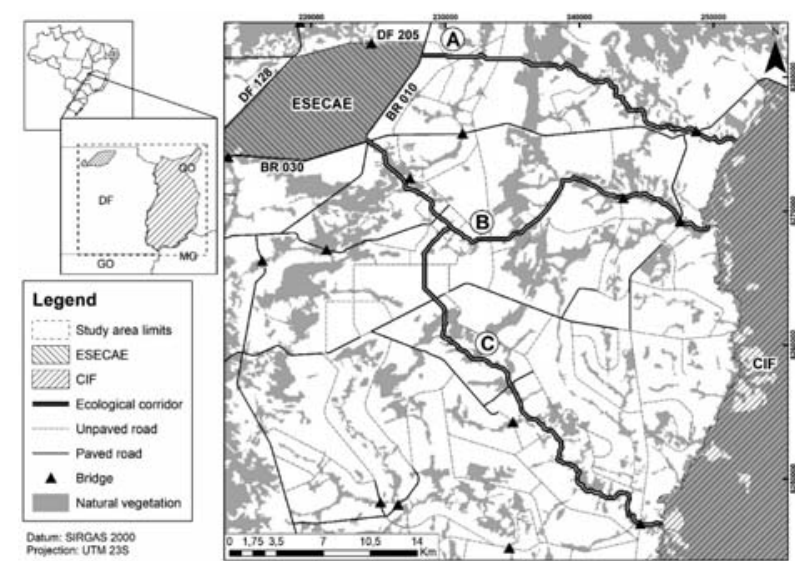

Figure 1 - Study area location and corridors A, B (best single path) and $C$ generated by cost path analysis.

Figura 1 - Localização da área de estudo e corredores A, $B$ (best single path) e C gerados por meio de análise de custo. routes used at least one bridge, and corridor B used two (Table 2).

The buffer generated to represent EC in full compliance with the CONAMA Resolution No. 9/1996 resulted in areas of 8,368.46 ha (A, smallest area), 12.294,24 ha (B) e 22.140,27 ha (C, biggest area). Overlap of the EC maximum area with land use and cover classes showed the predominance of three classes: Natural vegetation, with values ranging from $24.35 \%$ (C) to $35.64 \%$ (A); Annual crop with values ranging from $19.58 \%$ (A) to 48.84\% (C) and Pasture, with values ranging from 23.90\% (B) to $36.43 \%$ (A) (Table 2). In relation to rural properties, we opted to analyze only the path of lesser extent (A) and the least cost path (B), because they would probably present a lower implementation cost when compared to corridor $\mathrm{C}$, the one with longest extension. Corridor A intersects 16 properties and its area covers 51 properties, totaling 4318.25 ha (51.60\%) of the overlap. Corridor B, however, intersects 38 properties and totally or partially covers 79 properties, totaling 6228.95 ha (50.97\%) of overlap (Figure 2; Table 2).

\section{DISCUSSION}

The results in this work should be considered as predictive analysis of the viability of Ecological Corridors. Although the criteria and processes used are based on experts' opinion and on the literature, it is important

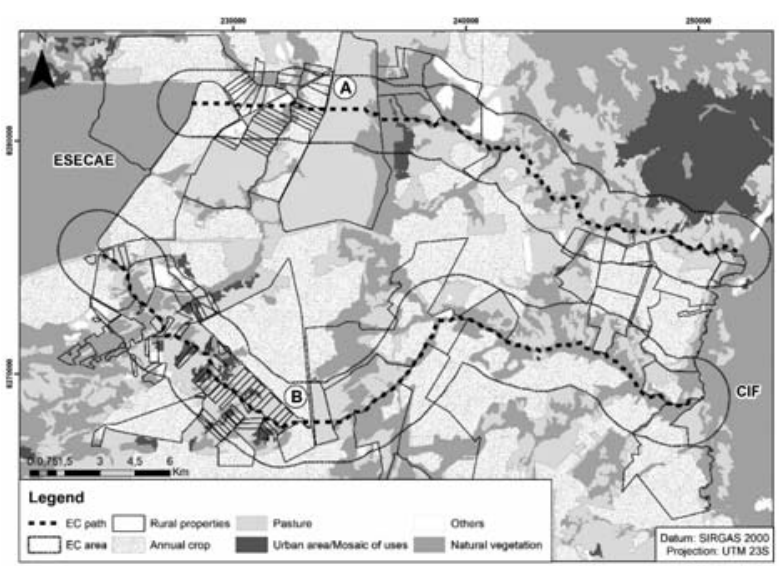

Figure 2 - Ecological Corridors (EC) A and B (best single path) over land cover classes and private properties map.

Figura 2 - Corredores Ecológicos (CE) A e B (best single path) sobrepostos a mapa de uso e cobertura do solo e limites de propriedades rurais.

Revista Árvore. 2017;41(6):e410611 
Table 2 - General information about the generated corridors. * Percentage refers to paths full extension. When considered only the extension inside APP, values change to: 94,38\% (A), 95,85\% (B), 97,23\% (C). ** Perennial crop, Urban area/Mosaic of uses, Water bodies, Forestry, Exposed soil, Non-observed.

Tabela 2 - Dados gerais dos corredores gerados. * A porcentagem refere-se à extensão total do traçado. Quando considerada apenas a extensão do trecho em APP, os valores são: 94,38\% (A), 95,85\% (B), 97,23\% (C). ** Agricultura perene, Área urbana/Mosaico de ocupação, Corpo d'água, Silvicultura, Solo Exposto e Não observado.

\begin{tabular}{|c|c|c|c|c|c|c|}
\hline & \multicolumn{2}{|c|}{ Corridor A } & \multicolumn{2}{|c|}{ Corridor B(Best Single) } & \multicolumn{2}{|c|}{ Corridor C } \\
\hline Extension & \multicolumn{2}{|c|}{28.88 km } & \multicolumn{2}{|c|}{$34.51 \mathrm{~km}$} & \multicolumn{2}{|c|}{$47.34 \mathrm{~km}$} \\
\hline Area & \multicolumn{2}{|c|}{$8,368.46$ ha } & \multicolumn{2}{|c|}{12,294 ha } & \multicolumn{2}{|c|}{$22,140.27$ ha } \\
\hline Trace intersection & $\mathrm{Km}$ & $\%$ & $\mathrm{Km}$ & $\%$ & $\mathrm{Km}$ & $\%$ \\
\hline Natural Vegetation & 21.50 & 74.43 & 31.18 & 90.35 & 41.41 & 87.47 \\
\hline Potential APP & 19.16 & 66.23 & 29.03 & 84.13 & 40.84 & 86.26 \\
\hline Preserved APP* & 18.04 & 62.59 & 27.83 & 80.64 & 39.71 & 83.88 \\
\hline Paved Roads & \multicolumn{2}{|c|}{1 un. } & \multicolumn{2}{|c|}{3 un. } & \multicolumn{2}{|c|}{5 un. } \\
\hline Unpaved roads & \multicolumn{2}{|c|}{4 un. } & \multicolumn{2}{|c|}{4 un. } & \multicolumn{2}{|c|}{4 un. } \\
\hline Bridges & \multicolumn{2}{|c|}{1 un. } & \multicolumn{2}{|c|}{2 un. } & \multirow{2}{*}{\multicolumn{2}{|c|}{$\begin{array}{c}1 \text { un. } \\
\text { Not evaluated }\end{array}$}} \\
\hline Rural properties & \multicolumn{2}{|c|}{16 un. } & \multicolumn{2}{|c|}{38 un. } & & \\
\hline Overlap area & ha & $\%$ & ha & $\%$ & ha & $\%$ \\
\hline Natural Vegetation & $2,982.80$ & 35.64 & $4,057.28$ & 33.00 & $5,390.26$ & 24.36 \\
\hline Annual Agriculture & $1,638.61$ & 19.58 & $4,136.26$ & 33.64 & $10,812.79$ & 48.84 \\
\hline Pasture & $3,048.40$ & 36.43 & $3,644.01$ & 29.64 & $5,290.92$ & 23.90 \\
\hline Other classes** & 698.64 & 8.35 & 456.69 & 3.71 & 649.3 & 2.92 \\
\hline Rural properties & $4,318.25$ & 51.60 & $6,228.95$ & 50.97 & No & ated \\
\hline
\end{tabular}

to validate this proposal with occurrence and movement patterns data of target species in the indicated areas (Chetkiewicz et al., 2006; Roy et al., 2010). Considering the lack of medium and large sized mammal records in the Federal District outside CU and immediate surroundings, field efforts and interviews with residents of the indicated areas could provide important information.

The tools and processes used in the present study were based on the work of Osborn and Parker (2003), Roy et al. (2010) Louzada et al. (2013), Ferrari et al. (2012) and Saito et al. (2016), prioritizing the selection of fragments of natural vegetation for the tracing of the Ecological Corridor. While Saito et al. (2016) proposed a corridor based on the identification of the most appropriate spots through GIS and AHP method, the other authors generated tracings using cost analysis, assigning weights on a scale of 1 to 255 (Roy et al., 2010) and 1 to 100 (Louzada et al., 2013; Ferrari et al., 2012). The present analysis differs from these works because it uses the AHP method to weight the class costs and the importance of the layers and, as opposed to Louzada et al. (2013) and Ferrari et al. (2012), it considers agricultural areas as eligible for the movement of some species (Calaça et al., 2010; Vynne et al., 2011; Arimoro, 2015), based on the concept of functional connectivity (Forero-Medina and Vieira, 2009; Seoane et al., 2010).
The intersection with areas of natural vegetation mostly in APP, certainly resulted from the addition of the APP layer with differentiated weight. This is appropriate considering the well-consolidated land use of most of the landscape and the legal obligation to maintain these areas. (Tabarelli et al., 2005). In addition, APP is a habitat widely used by most species of mammals in the Cerrado, with the exception of species that preferentially use open habitats, including cultivated and pasture areas, such as deer (Ozotocerus bezoarticus) and maned wolf (Chrysocyon brachyurus) (Vynne et al., 2011; Arimoro, 2015).

All corridors intersected at least one stretch under a bridge and at least one paved stretch, an important result considering the strong presence of roads and highways in the study area and the great impact of roads on wildlife, such as habitat loss and fragmentation, separation and barrier effects, behavioral changes and roadkill (Lang and Blaschke, 2009; Rosa and Bager, 2013). The points of intersection with roads must be compared with the known points of fauna crossing and trampling, in order to validate or adjust the route, or implement measures to ensure the safe crossing of animals, such as installation of signs, underground passages and road speed reduction (Clevenger et al., 2002; Osborn and Parker, 2003; Secretaria de Desenvolvimento Urbano e Meio Ambiente, 2008; Roy et al., 2010).

Revista Árvore. 2017;41(6):e410611 
Due to the greater extension of corridor $\mathrm{C}$ and its partial overlap with corridor $\mathrm{B}$ (best single path), the analysis of rural properties focused on the lowest cost (B) and lowest extension (A) routes. Path B, although intersecting three paved roads and 38 properties, presented the highest intersection value with natural vegetation (90.35\%). Corridor A, although intersecting less paved roads (1) and properties (16), showed smaller intersection with natural vegetation (62.59\%), which would require a greater effort for its implementation in terms of structural connectivity. Although corridor B represents the lowest accumulated cost, the two tracings could be treated as two complementary alternatives for connectivity of the study area, mainly through the maintenance and recovery of APP (Tabarelli and Gascon, 2005).

Corridors A and B intersect the area in which IBRAM proposed a Conservation Unit (Unidade de Conservação - UC), the Visconde de Porto Seguro Wildlife Refuge, reinforcing its potential for conservation (Secretaria de Desenvolvimento Urbano e Meio Ambiente, 2008). The proposal, however, has been stopped since 2008 due to the difficulty of implementation and by determination of the Court of Auditors of the Federal District (IBRAM, personal communication). The implementation of Ecological Corridors depends on Political decision-making and involves land issues. The situation of consolidated use of most of the studied landscape requires solutions that avoid expropriation and conflicts, like sustainable use UCs, or actions under the Rural Environmental Registry (CAR) or Environmental Regularization Programs (Iwama et al., 2014).

The fact that more than half of the corridors areas overlap to agriculture and pasture areas reveals the difficulty of implementing EC's with a preferred width of $10 \%$ of the total length. Implementation actions could, at a minimum, seek to maintain the current vegetation in corridor areas and ensure the minimum width of $100 \mathrm{~m}$ required by CONAMA Resolution No. 9/1996, although a minimum width of $300 \mathrm{~m}$ is recommended by some authors to increase the quality of the corridors (Tabarelli and Gascon, 2005).

The use of CAR information, although incomplete, shows its potential for environmental planning and conservation of biodiversity and leads to analysis at the level of rural properties. With CAR, the environmental agency can identify properties in disagreement with the legislation, and may suggest adherence to the
Environmental Regularization Programs (Programa de Regulamentação Ambiental - PRA). Excess vegetation may be recognized as Environmental Reserve Quotas (CRA) nominative titles comprising one hectare of native vegetation that can be purchased for compensation by owners in an irregular situation (Brasil, 2012; Sambuichi et al., 2014). The orientation of the PRA and the CRA market in the study area could consider the biodiversity component regarding the positioning of Legal Reserves, including opportunity cost analysis, seeking to maintain and recover areas for the implementation of corridors A and B.

The official data used in this study - TerraClass Project, roads and highways and hydrography and CAR data - met the needs of the analyzes, demonstrating their potential of use for the planning of actions for biodiversity. The generation, organization and availability of spatial data should be encouraged and supported, as well as capacity building for public managers in the use of available GIS data and tools (Lang and Blaschke, 2009).

Finally, it is important to mention that the spatial scale difference between the input data as well as the use of small-scale data (1: 250,000), can influence the final result of the analysis. If the approximation of the analysis at the property level is considered, the data should be compatible at a 1: 50,000 scale, as recommended in Ministry of the Environment Normative Instruction No. 2/2014 (Brasil, 2014a). However, the available data for multidisciplinary analyzes are rarely suitable or compatible and besides that, free data with greater detail or higher resolution are rarer due to the cost for its production ( Wu and Li, 2009).

\section{CONCLUSION}

The methodology developed and employed in this work, using Analytic Hierarchy Process (AHP) in addition to cost analysis tools with the proposed weight and cost values proved to be efficient in determining paths for the implementation of Ecological Corridors. The use of a layer related to the Permanent Protection Areas (APP) made it possible to identify lower implementation costs routes, intersecting vegetated areas with legal protection.

For the implementation of the Águas EmendadasFormosa Military Training Area Ecological Corridor, analysis of the B-path, and A-path as an alternative

Revista Árvore. 2017;41(6):e410611 
or complementary path, should be done considering land and political aspects involved. The results obtained in Geographic Information Systems (GIS) environment should be validated and adjusted if necessary through comparison with occurrence and movement data of target species in the corridor area, as well as roadkill records. Official data used for this analysis, despite possible accuracy issues derived from the multiple scales input data, have met the needs and have great potential of use for broader analyzes for biodiversity conservation.

\section{ACKNOWLEDGEMENTS}

Thanks to the Ministry of the Environment for encouraging and sponsoring training, and to IBRAM for the access to of data. Thanks to ESRI for the use of the Toolkit that is composed of the ArcGis 10.x Family through Contract No. 2011 MLK 8733, and the IMAGE for the support and feasibility of achieving the terms of use between the Institute of Geosciences and ESRI and for the support of the software.

\section{REFERENCES}

Akashi JJ, Castro SS. Corredores de biodiversidade como meios de conservação ecossistêmica em larga escala no Brasil: uma discussão introdutória ao tema. Rev. Bras. Cienc. Ambient. 2010;15:20-8.

Arimoro OAS. Uso de geotecnologias aplicadas em estudos de modelos de ocupação e conectividade para mamíferos de médio e maior porte no Cerrado [dissertação]. Brasília: Universidade de Brasília; 2015.

Batlle-Bayer L, Batjes NH, Bindraban PS. Changes in organic carbon stocks upon land use conversion in the Brazilian Cerrado: a review. Agric Ecosyst Environ. 2010;137(1-2):47-58. http:/ /dx.doi.org/10.1016/j.agee.2010.02.003.

Brasil. Conselho Nacional do Meio Ambiente. Resolução $n^{\circ}$ 9, de 24 de outubro de 1996. Define "corredor de vegetação entre remanescentes" como área de trânsito para a fauna. Diário Oficial da União, Brasília, 7 de novembro de 1996. Seção 1, p. 23069-70.

Brasil. Leis, Decretos etc. Presidência da República Casa Civil Subchefia para Assuntos
Jurídicos. Poder Legislativo. Lei n 12.651 de 15 de maio de 2012. Diário Oficial da União, Brasília, 15 de maio de 2012.

Brasil. Ministério do Meio Ambiente. Instrução Normativa $n^{\circ} 2$, de 06 de maio de 2014. Diário Oficial da União, Brasília, 7 de maio de 2014a.

Brasil. Ministério do Meio Ambiente. Lista Nacional Oficial de Espécies da Fauna Ameaçadas de Extinção. Portaria n ${ }^{\circ} 444$, de 17 de dezembro de 2014. Diário Oficial da União, Brasília, 18 de dezembro de 2014b.

Brasil. Ministério do Meio Ambiente. Mapeamento do uso e cobertura do Cerrado: Projeto TerraClass Cerrado 2013/MMA/SBF. Brasília: MMA; 2015.

Calaça A, Melo F, Marco P Jr, Jácomo AT, Silveira L. A influência da fragmentação sobre a distribuição de carnívoros em uma paisagem de cerrado. Neotropical Biology and Conservation. 2010;1(5):31-8. http:// dx.doi.org/10.4013/nbc.2010.51.05.

Chetkiewicz C-LB, St-Clair CC, Boyce MS. Corridors for conservation: integrating pattern and process. Annu Rev Ecol Evol Syst. 2006;37(1):31742. http://dx.doi.org/10.1146/ annurev.ecolsys.37.091305.110050.

Clevenger AP, Wierzchowski J, Chruszcz B, Gunson K. GIS-generated, expert-based models for identifying wildlife habitat linkages and planning mitigation passages. Conserv Biol. 2002;16(2):50314. http://dx.doi.org/10.1046/j.15231739.2002.00328.x.

Environmental Systems Research Institute. ArcGIS Desktop 10.3. New York: ESRI; 2014. CD-ROM.

Fahrig L. Effects of habitat fragmentation on biodiversity. Annu Rev Ecol Evol Syst. 2003;34(1):487-515. http://dx.doi.org/10.1146/ annurev.ecolsys.34.011802.132419.

Ferrari JL, Silva SF, Santos AR, Garcia RF. Corredores ecológicos potenciais na subbacia hidrográfica do córrego Horizonte, Alegre-ES, indicados por meio de SIG. Agraria. 2012;7(1):13341. http://dx.doi.org/10.5039/agraria.v7i1a1577.

Forero-Medina G, Vieira MV. Conectividade funcional e a importância da interação organismopaisagem. Oecol Aust. 2009;11(4):493-502.

Revista Árvore. 2017;41(6):e410611 
Instituto Chico Mendes de Conservação da Biodiversidade. Plano de Manejo da Área de Proteção Ambiental do Planalto Central. Brasília: MMA, ICMBIO, APA do Planalto Central; 2015.

Iwama AY, Lima FB, Pellin A. Questão fundiária em áreas protegidas: uma experiência no Parque Esta - dual da Pedra Branca (PEPB), Rio de Janeiro, Brasil. Soc Nat. 2014;23(1):77-93. http:// dx.doi.org/10.1590/1982-451320140106.

Klink CA, Machado RB. Conservation of the Brazilian Cerrado. Conserv Biol. 2005;19(3):70713. http://dx.doi.org/10.1111/j.15231739.2005.00702.x.

Lang S, Blaschke T. Análise da paisagem com SIG. São Paulo: Oficina de Textos; 2009.

Louzada FLRO, Santos AR, Silva AG, Oliveira OM, Oliveira GG, Mesquita PAG. análise multicritério e análise de percursos de menor custo aplicadas ao transporte de CO2 no mediterrâneo ocidental [dissertação]. Lisboa: Universidade Nova Lisboa; 2013.

Mittermeir RA, Fonseca GAB, Rylands AB, Brandon K. Uma breve história da conservação da biodiversidade no Brasil. Megadiversidade. 2005;1(1):14-21.

Muchailh MC, Roderjan CV, Campos JB, Machado ALT, Curcio GR. Metodologias de planejamento de paisagens fragmentadas visando a formação de corredores ecológicos. Floresta. 2010;40(1):147-62. http://dx.doi.org/10.5380/rf.v40i1.17106.

Oliveira APG, Mioto CL, Paranhos Filho AC, Gamarra RMG, Ribeiro AA, Melotto AM. Uso de geotecnologias para o estabelecimento de áreas para corredores de biodiversidade. Rev Arvore. 2015;39(4):595-602. http://dx.doi.org/10.1590/010067622015000400001 .

Osborn FV, Parker GE. Linking two elephant refuges with a corridor in the communal lands of Zimbabwe. Afr J Ecol. 2003;41(1):68-74. http:// dx.doi.org/10.1046/j.1365-2028.2003.00413.x.

Ribeiro JF, Walter BMT. Fitofisionomias do bioma Cerrado. In: Sano SM, Almeida SP. Cerrado: ambiente e flora. Planaltina: Embrapa Cerrados; 1998.
Rosa CA, Bager A. Review of the factors underlying the mechanisms and effects of roads on vertebrates. Oecol Aust. 2013;17(1):6-19. http:// dx.doi.org/10.4257/oeco.2013.1701.02.

Roy A, Devi BSS, Debnath B, Murthy MSR. Geospatial Modelling for Identification of Potential Ecological Corridors in Orissa. Photonirvachak. 2010;38(3):387-99. http:// dx.doi.org/10.1007/s12524-010-0042-6.

Saaty TL. Decision making with the analytic hierarchy process. Int J Serv Sci. 2008;1(1):83-98. http://dx.doi.org/10.1504/IJSSCI.2008.017590.

Saito NS, Moreira MA, Santos AR, Eugenio FC, Figueiredo AC. Geotecnologia e Ecologia da Paisagem no Monitoramento da Fragmentação Florestal. Floresta Ambient. 2016;23(2):201-10. http://dx.doi.org/10.1590/2179-8087.119814.

Sambuichi RHR, Silva APMD, Oliveira MACD, Savian M. Políticas agroambientais e sustentabilidade: desafios, oportunidades e lições aprendidas. Brasília: IPEA; 2014. p. 104-24.

Sano EE, Ferreira LG, Huete AR. Synthetic aperture radar ( $\mathrm{L}$ band) and optical vegetation indices for discriminating the Brazilian savanna physiognomies: a comparative analysis. Earth Interact. 2005;9(15):115. http://dx.doi.org/10.1175/EI117.1.

Secretaria de Desenvolvimento Urbano e Meio Ambiente. Águas emendadas. Brasília: SEDUMA; 2008.

Seoane CES, Diaz VS, Santos TL, Froufe LCM. Corredores ecológicos como ferramenta para a desfragmentação de florestas tropicais. Pesqui Florest Bras. 2010;30(63):207-16. http://dx.doi.org/ 10.4336/30.63.207.

Tabarelli M, Gascon C. Lições da pesquisa sobre fragmentação: aperfeiçoando políticas e diretrizes de manejo para a conservação da biodiversidade. Megadiversidade. 2005;1(1):181-8.

Tabarelli M, Pinto LP, Silva JMC, Hirota M, Bedê L. Challenges and opportunities for biodiversity conservation in the Brazilian Atlantic Forest. Conserv Biol. 2005;19(3):695-700. http://dx.doi.org/ 10.1111/j.1523-1739.2005.00694.x. 
Van Der Grift EA, Van Der Ree R, Fahrig L, Findlay S, Houlahan J, Jaeger JAG, et al.

Evaluating the effectiveness of road mitigation measures. Biodivers Conserv. 2013;22(2):425-48. http://dx.doi.org/10.1007/s10531-012-0421-0.

Vitousek PM, Mooney HA, Lubchenco J, Melillo JM. Human domination of earth's ecosystems. Science. 1997;277(5325):494-9. http://dx.doi.org/ 10.1126/science.277.5325.494.
Vynne C, Keim JL, Machado RB, Marinho-Filho J, Silveira L, Groom MJ, et al. Resource selection and its implications for wide-ranging mammals of the brazilian Cerrado. PLoS One. 2011;6(12):1-12. http://dx.doi.org/ 10.1371/journal.pone.0028939. PMid:22205984.

Wu H, Li ZL. Scale issues in remote sensing: a review on analysis, processing and modeling. Sensors. 2009;9(3):1768-93. http://dx.doi.org/ 10.3390/s90301768. PMid:22573986.

Revista Árvore. 2017;41(6):e410611 